\title{
The Settlement of Boundary Disputes Through Testing of Legislation in Indonesia
}

\author{
Suparto $^{1^{*}}$ and Rahdiansyah ${ }^{2}$ \\ ${ }^{1}$ Faculty of Law, Universitas Islam Riau, Pekanbaru, Indonesia. \\ ${ }^{2}$ Faculty of Law, Universitas Islam Riau, Pekanbaru, Indonesia.
}

\begin{abstract}
Boundary dispute is a new phenomenon that occurred in the era of regional autonomy followed by the expansion of the region. One of them occurred between Kepulauan Riau and Jambi Provinces related to Berhala Island ownership. Settlement of disputes between these two provinces took quite a long time and also caused tensions between two provinces. Actually, the government through the Ministry of Home Affairs has issued a regulation to solve the boundary problem of this area namely the Minister of Home Affairs Regulation No.1 in 2006 and No. 76 in 2012 on Guidelines for Confirmation of the Boundaries, however, is still less effective because although it has been done in such a way the party who feels aggrieved still take another way that is by testing the legislation to the Supreme Court or Mahkamah Konstitusional (Constitutional Court). An example is the boundary dispute between Kepulauan Riau and Jambi Province which was resolved through the examination of legislation to the Supreme Court and the Constitutional Court. In the case, there were 3 decisions, namely Supreme Court Decision No.49P/HUM/2011, Decision of the Constitutional Court No. 32/PUU-X/2012 and the decision of the Constitutional Court No. 62/PUU-X/2012. Based on the research results obtained as follows 1). Implementation of the principle or legal principle of lex posterior derogat lex priori by the Supreme Court 2). The decision of the Supreme Court was taken into consideration in the decision of the Constitutional Court 3). The cause of the territorial boundary disputes between Kepulauan Riau Province and Jambi Province was the synchronization of 3 related laws namely Indonesian Law no. 31 in 2003, Law no. 25 in 2002 and Law no. 54 of 1999.
\end{abstract}

\section{Introduction}

The disputes between territorial borders and territorial seizures are a new phenomenon that occurred along with the spreading of the region after the enactment of regional autonomy policy in 1999. Article 5 of Law Number 22 in 1999 on Regional Government provides opportunities for regions to establish or split regions. The opportunities are opened as an effort to improve people's welfare. However, in its implementation, new issues emerge, whether political, social, cultural, including territorial boundaries [1]. In its development, conflicts over regional or regional boundaries rise to a serious issue not just the question of boundaries between countries as it relates to the integration of the state [2].

There were several factors which can cause boundary conflicts, some of which occured more due to unclear territorial borders unsettled for a relatively long and did not occur any problems. However, along with regional autonomy, borders began to be disputed. Especially since the enactment of Law Number 33 in 2004 on Financial Distribution Between the Central Government and Local Government which mandate the existence of natural

\footnotetext{
* Corresponding author: suparto@law.uir.ac.id
} 
resources sharing fund, the existence of clear and definite boundaries becomes very important. With clear boundaries of territory, natural resources can be ascertained as to which regional administrative region. For that reason, the confirmation of regional borders is very important and crucial because it will provide clear boundaries of the authority of a certain regional government in running the government. The purpose of the regional boundary is to establish clear and definite boundaries both from the juridical aspect and from the physical aspects of the field [3].

Under the provisions of existing legislation, the setting of borders between regions is the authority of the central government in this case is the Minister of Home Affairs. The affirmation of regional boundaries has been guided by the Regulation of the Minister of Home Affairs (Permendagri) Number 1 of 2006 and No. 76 of 2012 on Guidelines for Affirmation of Regional Borders [4, 5]. The process of setting the boundary area can not always be done easily. In some areas with difficult topographic conditions, an ideal regional boundary is difficult to implement. This can not be separated from the interests of local governments who tend to defend their territory. This condition is related to the prestige of the leader or leader of an area who does not want if in his / her leadership there is a region that is loose in other areas, because if this happens it is very unfortunate for the concerned local head in the community's views.

The obscurity of boundary will result in two negative possibilities. First, a part of the region can be neglected by each local government because it feels it is not the region. Second, one local government can be considered beyond the limits of the authority of another because it equally assumes its territory. This has resulted in potential conflicts between regions and even a political impact on the border area [6].

The occurrence of territorial border disputes between regions is not only a matter of law, but also can spread to social problems. Regional border conflicts can have an impact on other conflicts such as social conflicts and natural resource conflicts [7]. Communities from two disputed areas are sometimes in a state of tension to defend their respective territories. For example in the dispute of ownership of Pulau Berhala between Kepulauan Riau and Jambi provincial governments. Therefore, there is a need for settlement measures that guarantee the end of the dispute over the ownership of the island, this is where the role of central government is very important and necessary.

To resolve the dispute over ownership of Berhala Island between Kepulauan Riau and Jambi Province, Minister of Home Affairs issued Regulation no. 44 in 2011 on the Territory of Pulau Berhala Administration which states that Pulau Berhala is entering Jambi region [8]. Kepulauan Riau Provincial Government objected to the issuance of the regulation, therefore Kepulauan Riau Provincial Government through the governor of Muhammad Sani filed a judicial review to the Supreme Court and based on the verdict. 49 P / HUM / 2011 dated February 9, 2011 The Supreme Court revoked the Minister of Home Affairs Regulation no. 44 Year 2011 on the Territory of Pulau Berhala Administration. But the issue is not settled there, because the Supreme Court only canceled Permendagri, but did not specify which territory the Berhala Island is and this is in accordance with the authority of the Supreme Court in deciding the case of Test Material. While on the other hand in Article 5 paragraph (3) Law No.25 of 2002 on the Establishment of Kepulauan Riau Province mentioned that the territory of Kepulauan Riau Province excluding Berhala Island [9]. This causes as if there are two contrary legislation provisions.

On the decision of the Supreme Court that canceled Permendagri then make Pulau Berhala into Jambi region. Jambi Provincial Government did not take it for granted and as the next legal step Jambi Provincial Government filed a judicial review of Act No.31 of 2003 on the Establishment of Lingga District to the Constitutional Court because in the law Berhala Island into Lingga Regency region [10]. Based on the decision of No.32 / PUU-X / 2012 the Constitutional Court rejected the petition. 
On the other hand, Lingga District Government itself also filed a judicial review of Law no. 25 of 2002 on the Establishment of Kepulauan Riau Province. The application of judicial review to the Constitutional Court was filed by Daria as regent of Lingga. The Petitioner examined the constitutionality of Article 3 of Law no. 25 of 2002 on the Establishment of Kepulauan Riau Province. The reason the applicant filed a judicial review because based on the law that Berhala Island entered the territory of Jambi Province. In the decision No. 62 / PUU-X / 2012 The Constitutional Court granted the petition of the petitioner.

\section{Research Methods}

In this study, researchers used normative legal research methods by way of literature study. The data used was secondary data that was Indonesian Law no. 54 in 1999, Law no. 25 of 2002, Law no. 31 of 2003, Regulation of the Minister of Home Affairs no. 44 of 2011, Minister of Home Affairs Regulation no. 1 of 2006, Supreme Court Verdict. 49 P / HUM / 2011, Decision of the Constitutional Court No. 32/PUU-X/2012 and Decision of the Constitutional Court No. 623/ PUU-X/ 2012 as well as from research results, journals, books and related legislation.

Data analysis was done qualitatively. The analysis phase began with data collection, then the data was presented by selecting, classifying systematically, logically and juridically to know the description specifically related to the problem in research, after which the writer did the interpretation or analysis. Then the authors compared with the theories and concepts of secondary data consisting of books of scientific books, journals, and related legislation and legal opinion of the expert of constitutional law.

\section{Discussions}

\subsection{Application of Lexical Principles or Legal Principles of Posterior Legal Derogat Lex Priori in the Decision of 'Mahkamah Agung' (Supreme Court)}

The ownership disputes of Berhala Island are very interesting to examine because they are finally resolved through judicial review of laws and regulations. The case raised 3 court decisions related to the testing of laws and regulations, namely a decision of the Supreme Court (decision No. 49P/HUM/2011) and 2 decisions of the Constitutional Court (decision No. 32/PUU-X/2012 and No. 62/PUU-X/2012). The first time a judicial review petition was filed by Kepulauan Riau Provincial Government to the Supreme Court on the issuance of Minister of Home Affairs Regulation no. 44 of 2011 About the Territorial Administration of Pulau Berhala, where in the letter mentioned that Pulau Berhala entered the province of Jambi. The Supreme Court has adjudicated the case with the decision No. 49 P / HUM / 2011 stating that the application of judicial review by Muhammad Sani as Governor of Kepulauan Riau against Regulation of the Minister of Home Affairs No. 44 of 2011 on the Territory of Pulau Berhala was granted.

One consideration of the Supreme Court Justice is in the laws of law known as the principle of lex posterior derogat lex priori meaning that the new provisions can ignore the old provisions [11]. Because of Law no. 31 of 2003 on the Establishment of Lingga District more then it can ignore the 2 previous Laws namely Law no. 54 of 1999 on the Establishment of Sarolangun Regency, Tebo District, Muaro Jambi Regency and East Tanjung Jabung Regency and Law no. 25 of 2002 on the Establishment of Kepulauan Riau Province. 
Although the researchers agreed with the results of the judicial review by the Supreme Court but did not agree with the consideration of the Supreme Court judge who used or applied the principle. According to the author lex posterior derogat lex priori can not necessarily be applied in this case, let alone this rule contains about the arrangement of territory. According to the researchers that the area precisely must be guided was the legislation of origin or beginning. For the case of Pulau Berhala although the most recent law (Law No. 31 in 2003) but because the law was about the expansion of the region (the division of Kepulauan Riau Province) should be guided by the law of origin or parent, namely Law No . 25 of 2002. According to the researchers the application of this principle can be done if the legislation regulates about the same material.

The Supreme Court judges also consider that based on historical facts or historically, since the period of Lingga Riouw Sultanate in 1957, Pulau Berhala was the conquest of the Sultan Lingga, and during the Dutch colonial period of 1922-1944 Pulau Berhala entered the Residentie Riouw region and listed in the map of Residentie Riouw en onderhoorigheden in 1922, overzichskaart van Sumatera blad 17 and Singkep map (first edition) Year 1743. Since early independence era of Pulau Berhala is still part of government territory of Kepulauan Riau Province, Riau Province based on Law Number 61 Year 1958 [12]. In addition Government Administration services in Pulau Berhala and small islands around it, as well as the construction of public facilities developed by the Government of Kepulauan Riau Province. Therefore, based on geographical historical facts and physical control of Pulau Berhala as described above, the defacto juridical of Pulau Berhala is entered into Lingga Regency Administration territory. Besides, other facts have proven that the guard officer of "Mercu Suar" in Berhala Island is from Navigation Tanjung Pinang, Kepulauan Riau Province, and not from other Provincial Navigation Service. This proves the goodwill of the Provincial Government of Kepulauan Riau (Lingga District Government) which has been so long continuously controlled physically and implement the governance of Pulau Berhala region by Kepulauan Riau Province [12]. From these considerations it can be explained that the evidence of the reinforcement so that the Supreme Court granted the request of Kepulauan Riau Provincial Government is a physical and real mastery as well as the administrative services carried out by Kepulauan Riau Provincial Government of Pulau Berhala.

\subsection{Decision of Supreme Court to be considered by the Constitutional Court Judge in issuing the decision No. 32 / PUU-X / 2012}

In this case the Constitutional Court issued two decisions related to the ownership of Pulau Berhala, namely Decision Number 32/PUU-X/2012 and Decision Number 62/PUU-X/2012. In the decision Number 32/PUU-X/2012 the Court rejects the petition of the petitioner, on the contrary in decision No. 62 / PUU-X / 2012 receives the petition of the petitioner.

Decision Number 32 / PUU-X / 2012, the petition filed by Hasan Basri Agus as Governor of Jambi. The Petitioner filed a petition for judicial review of Law Number 31 Year 2003 on the Establishment of Lingga Regency in Kepulauan Riau Province against. Particularly Article 5 paragraph (1) sub-paragraph c of Law 31 Year 2003 [13].

The provision of Article 5 paragraph (1) sub-paragraph c of Law 31 Year 2003 states that Lingga Regency has limits:

c. the south by Bangka Sea and Berhala Strait. According to the applicants, the provisions of Article 5 paragraph (1) sub-paragraph c of Law 31 Year 2003 do not limit and explain what is referred to as "Strait of Berhala". Unclear legal status of Pulau Berhala has impeded the exercise of the constitutional rights and / or authorities of the Jambi Provincial Government and Tanjung Jabung Timur Regency as autonomous regions as provided in Article 18 paragraph (2), paragraph (5), paragraph (6) and paragraph ( 7) of the 1945 
Constitution. In addition, according to the Petitioner the establishment of Law no. 31 of 2003 on the Establishment of Lingga Regency is not in accordance with the Indonesian Law no. 10 in 2004 on the Establishment of Laws and Regulations that have now been replaced with Law No.12 of 2011. In drafting a law should pay attention to the legal basis ("Considering"). In Law no. 31 of 2003 one of its legal basis ("Consider") is Law no. 25 of 2002 on the Establishment of Kepulauan Riau Province, therefore it is proper that the contents of the Law no. 31 of 2003 should not be contradicting much less related to territory. In its decision, the Constitutional Court rejected the petitioners' petition completely. This means that Pulau Berhala belongs to Lingga Regency [13].

One of the considerations of the judges of the Constitutional Court is as follows: ... The examination of the Act is done between the law against the 1945 Constitution, not tested by Law or otherwise, in this case of Indonesian Law No. 10 in 2004. The material of Law No. 10 in 2004 is intended to regulate the procedure of the formation of the Law good. The existence of deficiencies in the formation of the Law because it is not in accordance with the provisions contained in Law Number 10 Year 2004, does not immediately cause the law to be canceled. Laws that are not good the process of its formation may cause the material of the arrangement is less than perfect or the material can be contradictory to the 1945 Constitution, but can also produce a good regulation in terms of the theory of law formation. With that in mind, the Court does not conduct formal legal examination in accordance with any provisions contained in Law Number 10 in 2004, because if such matter is done the Court shall examine the Law against the Act, and it is not the intent of the 1945 Constitution. If the Court considers the existence of different arrangements, contained in different laws, prior to giving a decision on a case, it is intended to maintain consistency in the regulation in order to maintain legal certainty and not to test the substance of the Act against other laws . Indonesian Law no. 10 of 2004 is a law as well, which means that as the law in general can be a test object both formal and material, therefore can not be used as a basis for testing [13].

The interesting thing about this decision is the consideration of the Constitutional Court in its decision based on the Supreme Court Decision Number 49P / HUM / 2011 on the Material Test Rights of the Minister of Home Affairs Regulation No. 44 of 2011 on Pulau Berhala Administration Area.

In its consideration the Constitutional Justices shall submit the following matters; ... Since the legal matter has been decided by the Supreme Court in Decision Number 49 P / HUM / 2011, dated February 9, 2012 regarding the test of Regulation of the Minister of Home Affairs Number 44 Year 2011 dated September 29, 2011 concerning the Territory of Pulau Berhala Territory as mentioned above was the implementation of the Law, according to the Court, within the framework of the state law and in order to maintain legal certainty, without intending to judge the Decision of the Supreme Court, such decision became synchronized with the opinion of the aforesaid Court. The decision of the Supreme Court must be respected because it is still in its competence. Therefore, the Court on the grounds of respecting the correct legal product, the territorial boundary that has been canceled by the Supreme Court in Decision Number 49 P / HUM / 2011, dated February 9, 2012 was a legitimate law product and therefore must be respected. In addition, according to the Court the division of territory by the formulator of the Act was not contradictory to Article 18 paragraph (1) and paragraph (2), and Article 18A of the 1945 Constitution [13].

The decision of the Supreme Court as a consideration by the judges of the Constitutional Court became an interesting thing. Was it just a coincidence that between the decision of the Supreme Court and the Constitutional Court decision was the same result (the decision of the Constitutional Court to strengthen the decision of the Supreme Court)? If it did not mean that the Supreme Court's decision was made as a basic principle, it was rejected or granted an appeal then this became a bad precedent. The public can already guess that if there was a judicial review of the Constitutional Court Law, then it is certain that the result will be the 
same as the result of testing the related legislation that has been tested in the Supreme Court. Though it could be a law that made the test by the Supreme Court against the 1945 Constitution.

Interpretation of the Constitutional Court in resolving the dispute over ownership of Pulau Berhala by making the decision of the Supreme Court which has firstly decided the same case as a consideration to take the verdict. For reasons of recognition and respect for the existence of the Supreme Court, the Constitutional Court did not raise the argument of its decision on the exploration of the constitutionality of the Act against the 1945 Constitution but on the Supreme Court's decision [14]. Such a thing is not quite right, the Constitutional Court should examine the constitutionality of the law by interpreting the constitution as mandated by the constitution rather than relying on previous judicial decisions. Constitutional justices in interpreting the constitution, there are several ways or types, among others, grammatical, teleological, systematic, historical, comparative and futuristic interpretations [15].

After the issuance of the decision No.32/PUU-X/2012, the Constitutional Court issued the decision No. 62/PUU-X/2012 for the same case. The application of judicial review was filed by Daria as Regent of Lingga Regency. The petitioner examined the constitutionality of the explanation of Article 3 of Law No. 5/1999; No. 25 of 2002 on the Establishment of Kepulauan Riau Province stating that the territory of Kepulauan Riau Province did not include Pulau Berhala. The reason for the petition for filing a judicial review due to the explanation of Article 3 resulted in disruption of the administration of the government, the construction of infrastructure in Pulau Berhala funded by Kepulauan Riau Budget or the Lingga APBD. In addition, Elucidation of Article 3 of Law no. 25 of 2002 on the Establishment of Kepulauan Riau Province did not provide legal certainty regarding the constitutional authority of the applicant in carrying out regional government affairs specially in Pulau Berhala [16].

In its decision, the Constitutional Court granted the petition of the petitioner with the same legal consideration with the consideration of the previous decision because the object was the same namely the decision No. 32/PUU-X/2002, and states the Elucidation of Article 3 of Law Number 25 in 2002 on the Establishment of Kepulauan Riau Province was contradictory to the 1945 Constitution and has no binding legal force [16]. This decision is in line and reinforce the previous decision of the verdict No.32/PUU-X/2012. This reaffirms that Pulau Berhala belongs to Kepulauan Riau Province precisely in Lingga Regency.

\subsection{The source of the problem of the dispute is not the syncronize with the relevant legislation.}

The prolonged dispute over ownership of Pulau Berhala is actually caused by the lack of synchronization of the laws governing the expansion of the territory. There were at least 3 law products governing the splitting of regions whose regulatory objects included Pulau Berhala, namely: a) Law Number 31 in 2003 regarding the Establishment of Lingga Regency, b) Law Number 54 in 1999 about the Establishment of Sarolangun Regency, Tebo District, Kabupaten Muaro Jambi and Kabupaten Tanjung Jabung Timur, and c) Law Number 25 in 2002 regarding the Establishment of Kepulauan Riau Province. These three laws were not in syncronize with regulating the position of Pulau Berhala.

Article 5 paragraph (1) sub-paragraph c of Law no. 31 of 2003 on the Establishment of Lingga District did not limit and explained known as "Berhala Strait" and implicitly enter Berhala Island to Lingga Regency of Kepulauan Riau Province. Law No. 54/1999 on the Establishment of Sarolangun Regency, Tebo District, Muaro Jambi Regency and East Tanjung Jabung Regency, incorporated Berhala Island in Tanjung Jabung Timur Regency of 
Jambi Province [17]. Meanwhile, in the elucidation of Article 3 of Law no. 25 of 2002 on the Establishment of Kepulauan Riau Province explains that Kepulauan Riau Province in this law does not include Pulau Berhala, because Pulau Berhala has been included in the administrative area of Jambi Province in accordance with Law No. 54 of 1999 on the Establishment of Sarolangun Regency, Tebo District, Muaro Jambi Regency, and Tanjung Jabung Timur Regency, Jambi Province.

Expansion of the area that has lasted until now still leaves the problem related to the border area. It is therefore expected that in the formation of a law on the formation of an area the map scale of the annex is enlarged, so that the position of boundaries with adjoining areas becomes clear. Then in the process of expansion of the area associated with the boundary of the area which would be expanded with adjoining areas must first be resolved so that it does not become a problem in the future when an area is formed [18].

The emergence of loopholes to settle disputes boundaries to the Constitutional Court through the testing of the Act, because the formal legal formation of an autonomous region based on the provisions of the Act which one of its content material regulate the boundaries of autonomous regions associated with the boundaries areas with adjacent areas and their norms too common [19]. The settlement of territorial border disputes through judicial review is a common one, which is important to the applicant's compliance with the legal standing requirements. Legal standing requirements include formal requirements as defined by law, as well as material requirements in the form of constitutional rights or constitutional rights with the coming into effect of the law in question [20].

In the case of Pulau Berhala, the uniformity of the Berhala Island administrative standing in three laws creates serious legal disputes for local governments. Whereas if the harmonization and horizontal synchronization of the three laws are applied then the legal dispute can be avoided from the beginning. Therefore, it is the duty of lawmakers in this case the House of Representatives and the President to conduct synchronization of any laws that are made especially against the law concerning the boundaries of the territory in order to avoid future disputes.

\section{Conclusion}

In the settlement of the dispute between Pulau Berhala between Kepulauan Riau and Jambi Provinces through the examination of laws and regulations both in the Supreme Court and in the Constitutional Court, there are several conclusions that are (1). In the decision of No.49 $\mathrm{P} / \mathrm{HUM} / 2011$ the Supreme Court applied the legal principle of posterior lex derogat lex priori although this case concerns about the laws and regulations governing the border area as a result of the expansion of the region. (2). The decision of the Supreme Court is one of the considerations of the Constitutional Court judges in making the decision. 32/PUU$\mathrm{X} / 2012$. (3). The emergence of disputes between Riau Islands Province and Jambi Province associated with the ownership of Berhala Island due to the synchronization of the relevant law is Indonesian Law no. 25 in 2002 on the Establishment of Kepulauan Riau Province, Law no. 31 of 2003 on the Establishment of Lingga Regency and Law no. 54 of 1999 on the Establishment of Sarolangun Regency, Tebo District, Muaro Jambi Regency and Tanjung Jabung Timur Regency. 


\section{References}

1. F. L. Soeroso, Jurnal Konstitusi, 9, 166 (2015)

2. M. Septarina, Jurnal Al-Adl, VI, 2, (2014).

3. M. A. Hermana, Jurnal Sehasen, 1, 1 (2015).

4. Ministry of Home Affair Regulation No. 1 Year 2006.

5. Ministry of Home Affair Regulation No. 76 Year 2012.

6. A. Firmansyah, and K.C. Efendi, Jurnal JKAP, 18, 98 (2014)

7. S. Arifin, Jurnal Ius Quia Iustum, 23, 188 (2016)

8. Ministry of Home Affair Regulation No. 44 Year 2011.

9. Law No.25 Year 2002

10. Law No 31 Year 2003

11. J. Asshiddiqie, Perihal Undang-Undang, (Konstitusi Press, Jakarta, 2006)

12. Supreme Court Verdict No. 49 P/HUM/2011.

13. Constitutional Court Verdict No. 32/PUU-X/2012

14. M. Risnain, Jurnal Konstitusi, 11, 208 (2014)

15. Suparto, 1097 (2017)

16. Constitutional Court Verdict No.62/PUU-X/2012.

17. Law No. 54 Year 1999.

18. M. Indra, Menyelesaikan Sengketa Batas Daerah, ( Genta Publishing, Jakarta, 2015)

19. T. R. Erlando, Jurnal Online Mahasiswa (JOM), III, 193 (2016)

20. J. Asshiddiqie, Hukum Acara Pengujian Undang-Undang, (Konstitusi Press, Jakarta, 2006) 